\title{
EXPLODING THE ROLE OF RELIGIOUS INSTITUTIONS IN COMBATING CHILD TRAFFICKING IN NIGERIA
}

\author{
Alhaji Umar Alkali*, Laminu Bukar ${ }^{* *}$, and Goni Usman Ansari ${ }^{* * *}$ \\ Department of International Law Faculty of Law, University of Maiduguri \\ PMB 1069, Borno State, Nigeria
}

\begin{abstract}
Human trafficking is a global challenge especially in the $21^{\text {st }}$ Century. Nigeria like most developing countries is doing its best in addressing the menace of child trafficking. In view of the fact that religious institutions are highly respected in Nigeria, this paper intends to adopt a doctrinal methodology in examining the menace of child trafficking in Nigeria, by using the perspective of Islam and Christianity. Moreover, also seeing the role that can be played by the Supreme Council of Islamic Affairs and the Christian Association of Nigeria in the crusade against child trafficking in Nigeria.
\end{abstract}

Keywords: child, trafficking, Islam, Christian, Nigeria.

\section{Intisari}

Perdagangan manusia merupakan sebuah tantangan global pada abad ke-21. Sebagaimana negara berkembang pada umumnya, Nigeria melakukan upaya yang terbaik guna menangani ancaman perdagangan anak. Mengingat bahwa institusi keagamaan sangat dihormati di Nigeria, artikel ini bermaksud untuk mengadopsi metodologi doktrin dalam mengkaji ancaman perdagangan anak di Nigeria, melalui perspektif agama Islam dan agama Kristen perihal perdagangan anak. Selain itu, juga melihat peran yang dipegang oleh Dewan Tinggi Urusan Islam dan Asosiasi Umat Kristen Nigeria dalam perjuangan melawan perdagangan anak di Nigeria.

Kata Kunci: anak, perdagangan, Islam, Kristen, Nigeria.

\section{Pokok Muatan}

A. Introduction 519

B. Discussion

1. Human Trafficking 519

2. Human Trafficking in Nigeria 521

3. Child Trafficking in Nigeria 524

4. Religion and Human Trafficking 525

5. Role of Religious Institutions in Combating Child Trafficking ............................................... 526

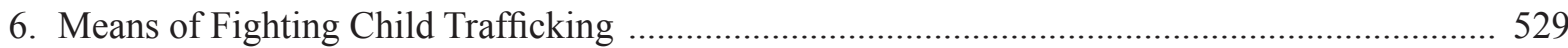

C. Conclusion 530

\footnotetext{
Correspondence address: umaralka@yahoo.co.uk

Correspondence address: tmbuba@yahoo.com

*** Correspondence address: usmanshanono@yahoo.com
} 


\section{A. Introduction}

Nigeria like many developing countries is faced with the challenge of human trafficking. Children are one of the common victims of such criminal activities largely due to their vulnerability and lack of exposure. The destination of such trafficked children if often Europe and some Arabian countries like Saudi Arabia. The approach of the Nigerian government has long been the arrest and sanction of persons involved in such illegal activity. In an effort to stem the fight against human trafficking, the Nigerian Government passed into the law the an anti trafficking law and established the NAPTIP (National Agency for the Prohibition of Trafficking in Persons) which is a body with the power to investigate, arrest and prosecute cases of human trafficking in Nigeria.

Though much has been achieved since the coming on board of NAPTIP, due to the fact that the perpetrators of this illegal activity get a lot of money in their activities, they devise various strategies and means to avoid prosecution. The importance of religious institutions in helping in the fight against human trafficking especially the NSCIA (Nigerian Supreme Council for Islamic Affairs) and the CAN (Christian Association of Nigeria) needs not be over emphasized. The good name they have established over the years and the respect they enjoy from Nigerians and indeed the government will greatly help in making a huge impact in this fight.

The legal problems examined by this paper includes the effectiveness of the legal instruments on child protection in Nigeria in fighting child trafficking, the position of Islamic law on the menace of child trafficking and how can religious bodies be used within the confines of the law in fighting child trafficking. This paper will therefore look how best religious institutions will be used in the fight against child trafficking in Nigeria and suggest ways through which the crusade can be achieved.

\section{B. Discussion}

\section{Human Trafficking}

Human trafficking is best described as modern day slavery. ${ }^{1}$ It has received increasing global attention over the past decade. Initially, trafficking of women and girls for forced sex work and, to a lesser extent, domestic servitude, were the sole focus of advocacy and assistance. Today, there is recognition that women, children and men are trafficked into many different forms of labour, and for sexual exploitation. ${ }^{2}$

The most widely cited definition of human trafficking is in the United Nations Protocol to Prevent, Suppress and Punish Trafficking in Persons (1), which defines human trafficking as the:

The recruitment, transportation, transfer, harbouring or receipt of persons, by means of the threat or use of force or other forms of coercion, of abduction, of fraud, of deception, of the abuse of power or of a position of vulnerability or of the giving or receiving of payments or benefits to achieve the consent of a person having control over another person, for the purpose of exploitation. ${ }^{3}$

Although women, men and children may all be trafficked for various purposes, trafficking is often a 'gendered' crime. Current evidence strongly suggests that those who are trafficked into the sex industry and as domestic servants are more likely to be women and children. ${ }^{4}$ Reports on trafficking of males indicate that men and boys are more commonly trafficked for various other forms of labour, and that these trafficking sectors generally

\footnotetext{
J. Koettl, 1999, Human Trafficking, Modern Day Slavery and Economic Exploitation, The World Band, Switzerland, p. 5.

M. Melrose, "Young People and Sexual Exploitation: A Critical Discourse Analysis", in M. Melrose, Palgrave Macmillan, 2013, Critical Perspectives on Child Sexual Exploitation and Related Trafficking, Palgrave Macmillan, Houndmills Basingstoke Hampshire, p. 15.

Protocol to prevent, suppress and punish trafficking in persons, especially women and children, supplementing the United Nations convention against transnational organized crime, G.A. res. 55/25, annex II, 55 U.N. GAOR Supp. (No. 49) at 60, U.N. Doc. A/45/49 (Vol. I) (2001), entered into force on 25 December 2003.

D.A. Feingold, “Think Again Human Trafficking”, http://faculty.maxwell.syr.edu/hpschmitz/PSC350/PSC350Readings/ThinkAgainHumanTrafficking.doc, accessed on 12 August 2014.
} 
differ by country or region. ${ }^{5}$

According to international and regional antitrafficking instruments, major forms of human trafficking include: forced labour, bonded labour, sex trafficking, debt bondage among migrant laborers, domestic servitude, child soldiers, child sex trafficking and forced begging. ${ }^{6}$

The most reputable and recent instruments of international law that have set the course for how to define, prevent, and prosecute human trafficking are the United Nations Convention against Transnational Organized Crime. ${ }^{7}$ The Convention is further supplemented by three Protocols, which target specific areas and manifestations of organized crime: ${ }^{8}$ (1) the Protocol to Prevent, Suppress and Punish Trafficking in Persons, Especially Women and Children; ${ }^{9}$ (2) the Protocol against the Smuggling of Migrants by Land, Sea and Air; ${ }^{10}$ (3) and the Protocol against the Illicit Manufacturing of and Trafficking in Firearms, their Parts and Components and Ammunition. ${ }^{11}$ The UNODC (United Nations Office on Drugs and Crime) created these conventions, which have supported international law's ability to combat human trafficking. ${ }^{12}$ In support of enforcing these instruments, the UNODC established the UN.GIFT (United Nations Global Initiative to Fight Human Trafficking) in 2007. ${ }^{13}$

Furthermore, additional tools of international law also come into play because they include segments against the trafficking of persons thus: (1) the Universal Declaration of Human Rights (1948),${ }^{14}$ (2) the International Covenants on Civil and Political Rights (1966), ${ }^{15}$ (3) The United Nations

World Health Organization, "Understanding and Addressing Violence Against Women”, www.who.int/iris/bitstream /10665/77394/1/WHO RHR_12.42_eng.pdf, accessed on 27 August, 2014.

M.S. Erudice, "Fighting Human Trafficking in Countries of Origin and Destination Improving Multidisciplinary Cooperation between Nigeria and European Countries", SAIK Journal, Vol. 1, 2012, p. 55.

The United Nations Convention against Transnational Organized Crime, adopted by General Assembly Resolution 55/25 of 15 November 2000, is the main international instrument in the fight against transnational organized crime. It opened for signature by Member States at a High-Level Political Conference convened for that purpose in Palermo, Italy, on 12-15 December 2000 and entered into force on 29 September 2003. See also United Nation Office on Drugs and Crime, "Conference of the Parties to the United Nations Convention against Transnational Organized Crime and the Protocols Thereto", http://www.unodc.org/unodc/treaties/CTOC/, accessed on 2 September, 2014.

8 Countries must become parties to the Convention itself before they can become parties to any of the Protocols. See also United Nation Office on Drugs and Crime, Ibid.

9 Adopted by General Assembly resolution 55/25. It entered into force on 25 December 2003. It is the first global legally binding instrument with an agreed definition on trafficking in persons. The intention behind this definition is to facilitate convergence in national approaches with regard to the establishment of domestic criminal offences that would support efficient international cooperation in investigating and prosecuting trafficking in persons cases. An additional objective of the Protocol is to protect and assist the victims of trafficking in persons with full respect for their human rights. See also United Nation Office on Drugs and Crime, Ibid.

10 The Protocol against the Smuggling of Migrants by Land, Sea and Air, adopted by General Assembly resolution 55/25, entered into force on 28 January 2004. It deals with the growing problem of organized criminal groups who smuggle migrants, often at high risk to the migrants and at great profit for the offenders. A major achievement of the Protocol was that, for the first time in a global international instrument, a definition of smuggling of migrants was developed and agreed upon. The Protocol aims at preventing and combating the smuggling of migrants, as well as promoting cooperation among States parties, while protecting the rights of smuggled migrants and preventing the worst forms of their exploitation which often characterize the smuggling process. See also United Nation Office on Drugs and Crime, Ibid.

11 The Protocol against the Illicit Manufacturing of and Trafficking in Firearms, their Parts and Components and Ammunition was adopted by General Assembly Resolution 55/255 of 31 May 2001. It entered into force on 3 July 2005. The objective of the Protocol, which is the first legally binding instrument on small arms that has been adopted at the global level, is to promote, facilitate and strengthen cooperation among States Parties in order to prevent, combat and eradicate the illicit manufacturing of and trafficking in firearms, their parts and components and ammunition. By ratifying the Protocol, States make a commitment to adopt a series of crime-control measures and implement in their domestic legal order three sets of normative provisions: the first one relates to the establishment of criminal offences related to illegal manufacturing of, and trafficking in, firearms on the basis of the Protocol requirements and definitions; the second to a system of government authorizations or licensing intending to ensure legitimate manufacturing of, and trafficking in, firearms; and the third one to the marking and tracing of firearms. See also United Nation Office on Drugs and Crime, Ibid.

12 L. King, "International Law and Human Trafficking", https://www.du.edu/korbel/hrhw/ researchdigest/trafficking/InternationalLaw.pdf, accessed on 9 September, 2014.

13 Ibid.

14 The Universal Declaration of Human Rights (UDHR) is a milestone document in the history of human rights. Drafted by representatives with different legal and cultural backgrounds from all regions of the world, the Declaration was proclaimed by the United Nations General Assembly in Paris on 10 December 1948 General Assembly resolution 217 A (III) (French) (Spanish) as a common standard of achievements for all peoples and all nations. It sets out, for the first time, fundamental human rights to be universally protected, See also United Nations Human Rights, "Office of the Commissioner for Human Rights”, http://www.ohchrorg/en/udhr/pages/introduction.aspx, accessed on 9 September, 2014.

15 Adopted and opened for signature, ratification and accession by General Assembly resolution 2200A (XXI) of 16 December 1966 entry into force 23 March 1976, in accordance with Article 49. 
Convention for the Suppression of the Traffic in Persons and of the Exploitation of the Prostitution of Others (1949), ${ }^{16}$ and (4) the Convention on the Elimination of all Forms of Discrimination Against Women (1979). ${ }^{17}$ These instruments laid the foundation for the contemporary conventions and efforts to eliminating trafficking.

Regional and domestic instruments that have played a key role in the prevention and elimination of human trafficking include: the United States Victims of Trafficking and Violence Protection Act (2000), ${ }^{18}$ the Council of Europe Convention on Action against Trafficking in Human Beings (2008), ${ }^{19}$ and the European Convention for the Protection of Human Right and Fundamental Freedoms (1950). ${ }^{20}$ Regions throughout the world are also making cooperative efforts to end trafficking. For example, in 2005, the COMMIT (Coordinated Mekong Ministerial Initiative against Trafficking), a sub-regional group composed of China, Laos, Thailand, Cambodia, Myanmar, and Vietnam, was established. ${ }^{21}$

The US Department estimates that a minimum of 700,000 people are trafficked each year and that the number may exceed 2 million. According to the US State Department there are an estimated 225,000 women and children who have been trafficked in South East Asia, ILO-IPEC estimated that 80,000 women and children have been trafficked to Thailand for sex trade since 1990 . The highest number are from Myanmar, followed by the Yunuah Province of China and Laos; According to ILO-IPEC an estimated 500-1000 Cambodian children work as child beggars in Thailand.22

Anti-trafficking laws are problematic to enforce because victims of trafficking are hesitant to identify traffickers for fear of repercussion. Furthermore, trafficking is a crime that transcends borders, and therefore issue of jurisdiction becomes a challenge. Applying international law to a person who resides in another state is a costly and complex endeavor. Additionally, human trafficking usually violates several laws, and is not a one-time event. Building a case against traffickers can take a great deal of time, resources, and energy. In countries where resources are limited, these complexities can hinder enforcement of anti-trafficking laws. ${ }^{23}$

Human trafficking is indeed a global problem especially in developing countries. Though several instruments of the United Nations have categorically condemned human trafficking in addition regional international instruments, prosecution of offenders poses great challenge due to the complexity of the crime and the internationalization of the activities as boarders are crossed in the process.

\section{Human Trafficking in Nigeria}

Certainly Nigeria is not the only country that is faced with the problem of human trafficking, however the fact remains that Nigeria is one of the leading countries in Africa in terms of human trafficking. ${ }^{24}$ It was reported by the Nigerian Police Force and the WOTCLEF (Women Trafficking and Child Labour Eradication Foundation) that between

\footnotetext{
Approved by General Assembly Resolution 317 (IV) of 2 December 1949 Entry into force: 25 July 1951, in accordance with Article 24.

Adopted in 1979 by the UN General Assembly, is often described as an international bill of rights for women. Consisting of a preamble and 30 articles.

18 United States Victims of Trafficking and Violence Protection Act is a federal statute passed into law in 2000 by the U.S. Congress and signed by President Clinton. The law was later reauthorized by Presidents Bush and Obama. It offers protections for persons in the country illegally who may be victims of human trafficking.

19 Entered into force on 1 February 2008, aims to prevent trafficking in human beings, protect victims of trafficking, prosecute traffickers, and promote co-ordination of national actions and international co-operation. The countries which have signed up to the Convention are monitored by the Group of Experts on Action against Trafficking in Human Beings (GRETA). The Council of Europe also supports governments in the implementation of the Convention and the recommendations emerging from its monitoring process. See Council of Europe, "Action Against Trafficking in Human Beings", http://www.coe.int/trafficking, accessed on 12 August 2014

20 Drafted in 1950 by the then newly formed Council of Europe, the convention entered into force on 3 September 1953.

1 L. King, Loc.cit.

22 A.M. Geshinde, and A. Elegbeleye, "An Investigation into Push Factors Sustaining Human Trafficking in Nigeria", Journal of Functional Management, Vol. 4, No. 1, 2001, p. 149.

23 L. King., Loc.cit.

24 A. Adepoju., "Review of Research and Data on Human Trafficking in Sub Saharan Africa", International Migration, Vol. 43, No. 1/3, 2005, p. 81 .
} 
March 1999 and April 2000, about 1,126 women trafficked out of the country were deported from various countries. ${ }^{25}$ Further statistics released by WOTCLEF, put the figure of trafficked Nigerian women deported as at December 2001 at about $5000 .{ }^{26}$

An ILO/IPEC report found that 40 per cent of Nigerian street children and hawkers are trafficked person. ${ }^{27}$ In March, 2002, WOTCLEF in a seminar organized by the International FIDA (Federation of Women Lawyers), reported that there are about 20,000 Nigerian women involved in the sex industry in Italy. Te Daily Champion of July, 2002 reported that 80 per cent of foreign prostitutes in Italy were Nigerian women. ${ }^{28}$

Mostly, the victims of human trafficking are women and children. Women and female children are often trafficked for sex or prostitution. The girl child is at a higher risk of being trafficked for prostitution compared to women due to her vulnerability. ${ }^{29}$ Sex trafficking is a particularly degrading form of human trafficking, defined generally as recruiting, enticing, harboring, transporting providing or obtaining either: an adult for commercial sex by force, fraud or coercion, or a juvenile for commercial sex, regardless of the means. Law enforcement and our nongovernmentorganization partners most often see cases in which pimps coerce women and girls. ${ }^{30}$

NAPTIP (National Agency for the Prohibition of Trafficking in Persons) operations are conducted through the support of four main units the Investigation Unit, ${ }^{31}$ Legal Unit, ${ }^{32}$ Public Enlightenment Unit ${ }^{33}$ and the Counseling and Rehabilitation Units. ${ }^{34}$ Also provided for in the enabling Act are "such other units as the Agency may establish with the approval of the Board". Similarly, there are at present six zonal offices within the country located at Benin, Lagos, Sokoto, Kano, Enugu and Abuja; while plans are underway to create NAPTIP state offices. ${ }^{35}$ Nigeria has 36 states and a Federal Capital Territory at Abuja. ${ }^{36}$ Because Benin in Edo State of Nigeria is a trafficking endemic area, there exists a law also that makes human trafficking and prostitution of any kind, local or international, punishable offenses. ${ }^{37}$

A variety of so-called 'push' and 'pull' factors contribute to human trafficking. ${ }^{38}$ Poverty; political and social and economic instability; crises; unequal access to education, particularly for women; restrictive migration channels and inadequate information about legal migration opportunities as well as traditional community attitudes and practices which tolerate violence against women constitute some of the push factors. ${ }^{39}$ Among the pull factors the demand for cheap products or services plays

O. Agbu, Daily Times of $14^{\text {th }}$ June 2001, p. 4

O. Agbu, "Corruption and Human Trafficking: The Nigerian Case", West African Review, Vol. 4, No. 1, 2003 , pp. 1-13.

ILO/IPEC, 2000, Combating Trafficking in Children for Labour in West and Central Africa, ILO/IPEC, Geneva, p. 43.

28 V.N. Opara, "Consent Dilemmas: Contextualising the Trafficking of African, Asian, \& Eastern European Women for Prostitution", http:// aa.ecn.cz/img upload/9e9f2072be82f3d69e3265f41fe9f28e/VOpara Dilemma of Consent after Alices review.pdf., accessed on 8 September 2014

29 N.B. Busch-Armendariz, et al., 2009, Understanding Human Trafficking: Development of Typologies of Traffickers, Institute on Domestic Violence and Sexual Assault, USA, p. 23.

30 R. Moossy, "Sex Trafficking: Identifying Cases and Victims", NIJ Journal, Issue No. 262, 2010, p. 34.

31 This is the unit of NAPTIP that is in charge of investigation of the crime of trafficking. They conduct field operations and arrest people involved or suspected of trafficking.

32 The legal unit conducts the actual prosecution in the courts and has lawyers that are dedicated to the prosecution of cases of trafficking.

33 The Public Enlightenment unit deals with anti trafficking campaigns using the media, drama, visitation to communities etc.

34 The Rehabilitation unit is concerned with the rehabilitation of the victims of trafficking so that they can fit and live a normal life.

35 The need for the establishment of these offices is informed by the fact that the states where the zonal offices are created are the flash points and serve as exit route for traffickers.

36 Section 3 (1) of the 1999 Constitution provides. "There shall be 36 states in Nigeria, that is to say, Abia, Adamawa, Akwa Ibom, Anambra, Bauchi, Bayelsa, Benue, Borno, Cross River, Delta, Ebonyi, Edo, Ekiti, Enugu, Gombe, Imo, Jigawa, Kaduna, Kano, Katsina, Kebbi, Kogi, Kwara, Lagos, Nasarawa, Niger, Ogun, Ondo, Osun, Oyo, Plateau, Rivers, Sokoto, Taraba, Yobe and Zamfara".

37 O. Ogbu, "Revisiting Corruption and Human Trafficking in Nigeria: Any Progress?", www.ungift.org/docs/ungift/pdf/vf/backgroundpapers/ OsitaAgbu_1.pdf, accessed on 30 August, 2014.

38 A.P. Jorge-Birol1, "Empowering Victims of Human Trafficking: The Role of Support", Assistance and Protection Policies HUMSEC Journal, Issue 2, 2008

39 Ibid. 
an important role. Other factors such as corruption contribute to the persistence of human trafficking. ${ }^{40}$

Human trafficking has devastating consequences on its victims and the public as a whole reported that the UNICEF (United Nations Children's Fund) has found out that trafficked children are frequently subjected to sexual and physical abuse, lose all contact with family members and a stable environment, receive little or no education, and may suffer serious health problems and a high risk of early death. ${ }^{41}$ Similarly, health officials insist that trafficking in women causes significant health risks to the general public, especially in terms of sexually transmitted diseases because women sold into prostitution are often discouraged or forbidden from using contraceptives such as condoms and thus become high-risk candidates for the spread of diseases. ${ }^{42}$ Trafficking victims are forced to endure intercourse with multiple partners. They are also hired for pornography and bestiality. These conditions or experiences make the women vulnerable to multiple abortions, sexually transmitted diseases (STDs) and other female reproductive health challenges that are increasingly responsible for the spread of HIV/ AIDS

More so, violence is also common in commercial sex and particularly prevalent when a woman is forcibly subjected to sex against her will. Injuries and abrasions sustained from this could heighten her physical vulnerability to HIV transmission. Especially also, the vulnerability of trafficking victims to sexually transmitted diseases (STDs) and HIV/AIDS is further compounded by their inability to receive timely medical test, treatment, counseling and prevention services because they want to evade immigration laws. ${ }^{43}$ Similarly, human trafficking also points to the fact that human rights are violated while talent and human resources are pushed out of Africa. ${ }^{44}$

According to the United Nations Protocol to Prevent, Suppress and Punish Trafficking in Persons:

Each State Party shall consider implementing measures to provide for the physical, psychological and social recovery of victims of trafficking in persons in particular, the provision of: (a) Medical, (b) psychological and (c) material assistance. ${ }^{45}$

Human trafficking generally is organized around five participants. First, it involves migrant victims who are trafficked and transported out of Nigeria. Second, involves those who recruit victims for transport, and in most cases take charge of finances by paying for all transportation costs. Some of these people stay in Nigeria while others stay outside the country. Third, are buyers who claim ownership or possession of the victim. In most cases buyers do not have any pre-existing relationships with the victim; hence the buyer may use force and coercion to maintain compliance of the victim into submission and they are always outside the country. Fourth, are the enablers, those who work behind the scenes either knowingly or unknowingly by assisting in facilitating the movement of victims from one place to another. This is imminent in developing countries in Africa, Asia and South America, where human traffickers can beat the system without getting caught. ${ }^{46}$ Fifth, consumers or buyers of sex prostitutes from pimps who offer

40 Marquez Sanchez Erudice, "Fighting Human Trafficking in Countries of Origin and Destination, Improving Multidisciplinary Cooperation between Nigeria and European Countries", SIAK Journal, Vol. 1, 2012, p. 57.

41 United Nations International Children's Fund, "Child Protection", http://www.unicef.org/dump/9482.html, accessed on 6 September 2014.

42 A.M. Geshinde and Elegbeleye, Op.cit., p. 150.

43 M.D. Enaikele and A.O. Olutayo, "Human Trafficking in Nigeria: Implication for Human Immune Deficiency Virus and Acquired Immune Deficiency Syndrome (HIV/AIDS) Pandemic”, International Journal of Sociology and Anthropology, Vol. 3, No. 11, 2011, p. 420.

44 A. M. David- Odigie, "Human Trafficking Trends in Nigeria and Strategies for Combating the Crime", Peace Studies Journal, Vol. 1, No. 1, 2008, pp. 63-75.

45 Duru E.J.C. and Maurice O.U., "Combating Human Trafficking in Nigeria: An Evaluation of State Policies and Programmes", Mediterranean Journal of Social Sciences, Vol. 3, No. 3, September 2012, p. 162. UN. Protocol to prevent, suppress and punish trafficking in persons, especially women and children, supplementing the United Nations convention against transnational organized crime. General Assembly Resolution 55/25. New York, NY, United Nations General Assembly, 2000.

46 Examples of these countries are Nigeria and Thailand. 
clientele services on hourly bases at the expense of the victim. Sixth, government and NGOs who play a significant role in rehabilitating victims (if they are ever recovered) from human trafficking menace for example NAPTIP. ${ }^{47}$

\section{Child Trafficking in Nigeria}

A child according to the Child's Right Act 2003 is any person below the age of 18 years. ${ }^{48}$ Several other laws in Nigeria have equally defined a child. The 1999 Constitution of the Federal Republic of Nigeria recognizes the age of 18 as the age of voting. ${ }^{49}$ This by implication means that the constitution is recognizing 18 years as the age of majority. According to the Children and Young Person's Act ${ }^{50}$ "a "child" means a person under the age of 14 years, while "young person" means a person who has attained the age of 14 years and is under the age of 17 years." ${ }^{11}$ In a similar vein, the Immigration Act stipulates that any person below 16 years is a minor. ${ }^{52}$ The Marriage Act on the other hand fixes the age of maturity at 21 years. ${ }^{53}$ Further, the Matrimonial Causes Rules puts the age of majority at $21 .{ }^{54}$ The Convention on the Rights of the Child equally defines a child as [...] every human being below the age of eighteen years $[\ldots] .{ }^{55}$ Similarly, the African Charter on the Rights and Welfare the Child ${ }^{56}$ defines a child as a human being below the age of 18 years. ${ }^{57}$

Trafficking in children according to international law does not necessarily need to involve the use of force, deception or any other means. It is only necessary to show: (1) an "action" such as recruitment, buying and selling; and (2) that this action was for the specific purpose of exploitation. ${ }^{58}$ In other words, trafficking will exist where the child was subjected to some act, such as recruitment or transport, the purpose of which is the exploitation of that child. This definition potentially makes easier to identify child victims of trafficking and their traffickers. However, its breadth may make it difficult to distinguish those who have been trafficked from the broader category of children on the move..$^{59}$

Nigeria is signatory to several international conventions against trafficking, prominent among these are: ${ }^{60}$

a. United Nations Convention on the Declaration of Human Rights (1948); ${ }^{61}$

b. United Nations Convention on Elimination of All Forms of Discrimination Against Women (1979); ${ }^{62}$

c. United Nations Convention on the Rights of the Child (1989); ${ }^{63}$

d. International Labour Organization Convention on Forced Labour and Minimum Wage (1999);

e. United Nations Optional Protocol to the Convention on the Rights of the Child, especially on the Sales of a

\footnotetext{
47 M.A. Rahman, "Human Trafficking in the Era of Globalization: The Case of Trafficking in the Global Market Economy", Transcience Journal, Vol. 2, No. 1, 2011, p. 58.

48 Section 277 Child's Right Act (CAP M7 Laws of the Federation of Nigeria 2004).

49 Section 29 of the 1999 Constitution which provides that full age means 18 years and above. Section 2 of the Electoral act equally stipulates 18 years as the age of voting.

Enacted in Eastern, Western and Northern Regions of Nigeria.

Article 2 of the Children and Young Persons Act (CAP 22 Laws of the Federation of Nigeria 2004).

Section 37 (1) of the Immigration Act (CAP 171 Laws of the Federation of Nigeria 1963).

Section 48 of the Marriage Act (CAP C218 Laws of the Federation of Nigeria 1990). See also section 18 of the Marriage Act (CAP C218 Laws of the Federation of Nigeria 1990).

Order 1 Rule 4 of the Matrimonial Causes Act (CAP M7 Laws of the Federation of Nigeria 1970).

Article 1 of The United Nations Convention on the Rights of the Child.

Adopted in Addis Ababa, Ethiopia on July 1990 and entered into force on 29 November 1999.

Article 2 of The United Nations Convention on the Rights of the Child.

58 Department of State United States of America, "Trafficking in Persons Report", www.state.gov/documents/organization/142979.pdf, accessed on 6 September 2014.

59 A. Gallagher, et al., 2010, Recommended Principles and Guidelines on Human Rights and Human Trafficking, United Nations, New York, p. 28.

60 Adopted by General Assembly resolution 55/25 of 15 November 2000.

61 This UNDHR came on after the second world war to address the cruelties witnessed during the war.

62 Nigeria signed CEDAW on 23 April 1984 and ratified it on 13 June 1985.

63 The CRC is the first binding International treaty on child Protection. It was adopted by 159 members of the United Nations General Assembly in 1989 and its optional Protocols ratified by 145 countries including Nigeria.
} 
Child, Child Prostitution and Child Pornography (2002); ${ }^{63}$ and

f. United Nations Convention Against Transnational Organized Crime (2000). ${ }^{64}$

Others include the African Charter on Human Rights (1980); ${ }^{65}$ the Protocol on the Rights of Women in Africa (1981); ${ }^{66}$ Africa Charter on the Rights and Welfare of the Child (1990), ${ }^{67}$ and the Economic Community of West Africa States (ECOWAS) Declaration and of Action against Trafficking in Persons (2001). ${ }^{68}$

At the national level, the 1999 constitution of the Federal Republic of Nigeria provides for the respect and dignity of human persons. It provides in section 34 (1) that no person shall be subjected to torture, in human or degrading treatment or held in slavery or required to perform compulsory labour. ${ }^{69}$

The rights of the citizens to the dignity of the human person against slavery, servitude, forced labour, prostitution and other forms of sexual exploitation is also enshrined in the criminal Code $^{70}$ and the Penal Code ${ }^{71}$; Labour Act ${ }^{72}$; and the Trafficking in Persons Law Enforcement and Administration Act. $^{73}$

The anti-human trafficking act is the most recent and crucial because it specifically addresses human trafficking. This anti-human trafficking law was a laudable move that culminated in the establishment of the NAPTIP (National Agency for Prohibition of Trafficking in Persons). There are several provisions of the antihuman trafficking act of NAPTIP prescribing different punishment ranging from one year to life imprisonment for serious offences such as exportation or importation of girls under the age of 18 years for prostitution, forced labour, servitude or removal of organ by means of threat or use of force or other forms of coercion, abduction, fraud or deception. ${ }^{74}$ The law has in categorical terms provided for the arrest and prosecution of any person involved in human trafficking. It states that where an offence under the act is committed by any citizen or person granted permanent residence in Nigeria, he may be prosecuted in respect of such offence as if it was committed in any place within Nigeria. ${ }^{75}$

Similarly, the Act has further vested the power to arrest, search and seize on police, immigration, custom and NAPTIP (National Agency for Prohibition of Trafficking in Persons) officials. Similarly, the Federal and State High Courts have concurrent jurisdiction to try any of the offences under the law. ${ }^{76}$

\section{Religion and Human Trafficking}

The act of trafficking in children constitute a wrong in the eyes of both Islam and Christianity, reason being that the victims are exposed to all forms of violence and exploitation which is utterly condemned by both the Qur'an and the Bible. Looking at the consequences of trafficking on its victims and the society at large, one cannot help but

\footnotetext{
${ }_{64}$ Nigeria ratified the First Optional Protocol on the Involvement of Children in Armed Conflict on 25 September 2012 and the Second on the Sale of Children, Child Prostitution and Child Pornography on 27 September, 2010. See also United Nations Human Rights, "Reporting Status for Nigeria", http://tbinternet.ohchr.org/layouts/TreatyBodyExternal/Countries.aspx? CountryCode $=N G A \& L a n g=E N$, accessed on 23 January, 2014.

65 The African Charter on Human and Peoples' Rights was drafted in Banjul, The Gambia, in June 1980 to January 1981 . In June 1981 during the $18^{\text {th }}$ General Assembly meeting the Organization for African Unity (OAU) Heads of States approved the Charter in Nairobi, Kenya, and it entered into force in October 211986.

66 The Women's Rights Protocol was adopted by the African Union in July 2003 as a result of intensive advocacy by many organizations from all over Africa and entered into force on 25 November 2005. As of May 2011 it has been ratified by 30 countries.

Nigeria signed it on $13^{\text {th }}$ July, 1999 and ratified it on 23 June 2001.

Twenty-Fifth Ordinary Session of Authority of Heads of State and Government Dakar, 20 $0^{\text {th }}-21^{\text {st }}$ December, 2001.

M.D. Enaikele and A.O. Olutayo, Op.cit., p. 420.

Criminal Code (CAP C38 Laws of the Federation of Nigeria 2004).

Penal Code (CAP P3 Laws of the Federation of Nigeria 2004).

Labour Act (CAP L1 Laws of the Federation of Nigeria 2004).

Trafficking in Persons Law Enforcement and Administration Act (CAP 24 Laws of the Federation of Nigeria 2003).

Sections 11 to 29,32 and 46 .

Section 61(1).

M.D. Enaikele1 and A.O. Olutayo, Op.cit., p. 450.
} 
state that no religion will accept such an inhumane act.

Authorities from the Qur'an and traditions of the Prophet (PBUH) have clearly indicated that it is wrong for a person to harm another. The Qur'an states "Indeed, the wrongdoers will not succeed". ${ }^{77}$ The Messenger of Allah equally mentioned "Do not harm and do not be harmed". ${ }^{78}$

The Bible is clearly against wrong actions and wrongfully causing any form of harm to people especially children. ${ }^{79}$ The bible says "Live in harmony with one another" which is the opposite of harming. ${ }^{80}$ Children are seen as human beings that deserve to be loved, cherished and protected. God gave a high compliment to Abraham when he said of him, "I know him, that he will command his children and his household after him, and they shall keep the way of the Lord". ${ }^{81}$ Human trafficking has no place under Christianity and Christians have become increasingly significant players in activism to end human trafficking even though Christian anti-trafficking activism and advocacy is marked by considerable internal variation. ${ }^{82}$

It is clear that the child trafficking has no place under both Islam and Christianity unfortunately most of the people involved in child trafficking are either Muslims and Christians these therefore makes the role of religious institutions in the fight against human trafficking exceedingly important.

\section{Role of Religious Institutions in Combating Child Trafficking}

No doubt, religious institutions have a significant role to play in terms of the fight against human trafficking. ${ }^{83}$ In Nigeria, there are two main religious bodies that represent the vast majority of the Muslims and Christians and they could play a very significant role in the fight against human trafficking.

\section{a. The Nigerian Supreme Council for Islamic Affairs (NSCIA) \\ NSCIA is the main body that represents} the Muslims in Nigeria. This body was formed in 1973 under the auspices of JNI (Jamatu-Nasril-Islam) which is the umbrella body for all the Islamic organizations in Northern Nigeria. ${ }^{84}$ The assembly wanted the proposed Council to "act as a bridge between the various Muslim communities in Nigeria and also enable Muslims to speak to the government of the day in one voice on matters concerning Islam. ${ }^{85}$ The emergence of the Council in 1973 has been described as "the culmination of many years of tireless efforts to get Muslims in this country under one central organization". A major contributory factor in the quick formulation of the Council was the Nigerian Muslims' failure to speak with one voice at an international Islamic Conference held in Libya earlier in the same year and to which various Islamic organisations were invited from Nigeria. Every Nigerian delegate at the conference rose strongly to protect the interest of his own organisation and not that of the generality of the Nigerian Muslims whereas their counterparts from other countries found no strain in making common presentations. ${ }^{86}$ Back at home, a quick move was made towards the fulfillment of the need for a central Islamic body which was formally inaugurated as NSCIA in $1974 .{ }^{87}$ The council is headed by the sultan of Sokoto his Royal Highness

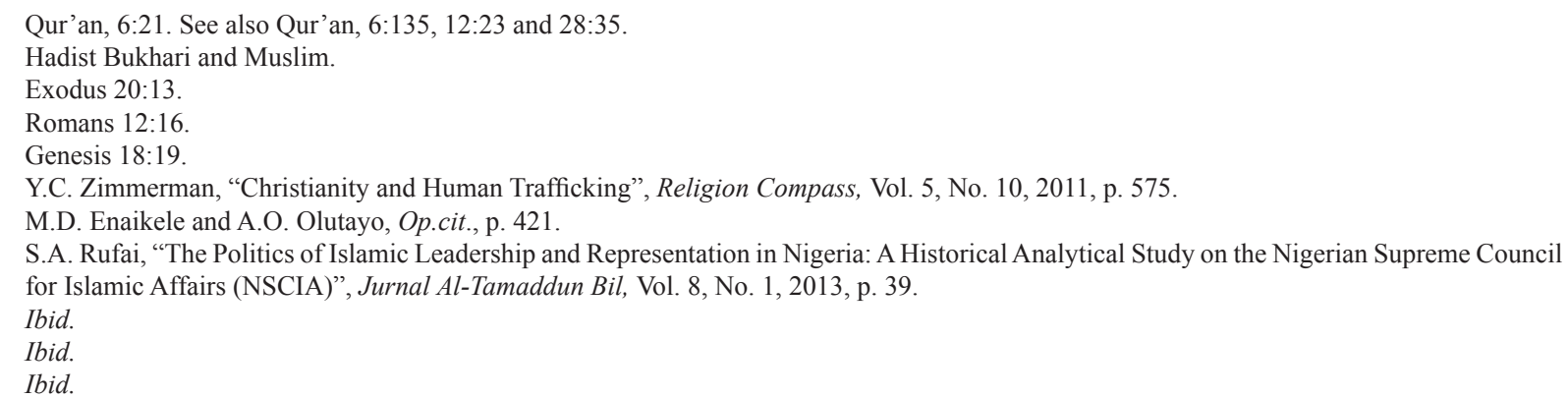


Alhaji Muhammad Sa'adu Abubakar III as the President General ${ }^{88}$ and the Deputy President General is his Royal Highness the Shehu of Borno Alhaji Abubakar Ibn Garbai Elkanemi ${ }^{89}$ The body is primarily aimed at protecting the interest of Islam and Muslims in Nigeria. The Constitution of the NSCIA provides: ${ }^{90}$

The Council is established to cater for; preserve, protect, promote and advance the interests of Islam and the Muslims throughout Nigeria. To this end the Council shall:

Paragraph

(1) Promote Islamic solidarity through fostering brotherhood and cooperation among Muslims in Nigeria and other parts of the World.

(2) Promote the continued application of Shari'ah in Nigeria and the observance of Islamic morality. The Council shall therefore, ensure that the ideals of Islam as laid down in the Glorious Qur'an and the Sunnah of the Holy Prophet Muhammad (P.B.U.H) are adhered to by all Muslims in Nigeria.

(3) Serve as a channel of contact with the GovernmentAuthorities on Islamic Affairs.

(4) Ensure uniform observance of Islamic rites including Festivals throughout the Federation of Nigeria.

(5) Coordinate the external contacts, interests and activities of Muslims in Nigeria as individuals or groups. The Council acting thus be the channel of contact and communication with external bodies on Islamic matters.
(6) Establish and encourage the establishment of institutions of learning wherein Islamic studies, and Islamic culture as well as the Arabic language and other subjects of general professional and vocational education shall be taught.

(7) Promote better understanding and practice of Islam. To this end the Council shall encourage Da'awah. It shall also promote the true image of Islam through the use of mass media, publications and other means.

(8) Build, manage and support Mosques in Nigeria and elsewhere.

(9) Cater for the social welfare of Muslims and others. To this end the Council shall establish and encourage communities and organizations to establish hospitals and other health institutions, hostels, recreation centers and such other social facilities as may be required.

(10) Promote the establishment of Islamic economic system in Nigeria and encourage all Muslims to engage in legitimate economic activities. The Council shall also encourage Muslims to lead a life of thrift and economy.

(11) Hold, acquire and dispose of any property whether movable or immovable.

(12) Engage in any lawful activities in fulfillment and furtherance of the foregoing aims and objectives.

The Head quarters of NSCIA is in the Federal Capital Territory Abuja ${ }^{91}$ While the membership of the body includes all Muslims Communities, Islamic Organizations and

\footnotetext{
Article 15 (1) Constitution of the Nigerian Supreme Council for Islamic Affairs. See also The Muslim 500, “Amirul Mu'minin Sultan Muhammadu Sa'adu Abubakar III", http://themuslim500.com/profile/saadu-abubakar-iii-sultan-sokoto, accessed on 19 August, 2014.

Article 15 (2) Constitution of the Nigerian Supreme Council for Islamic Affairs

Article 3 Constitution of the Nigerian Supreme Council for Islamic Affairs.

Article 2 Constitution of the Nigerian Supreme Council for Islamic Affairs.
} 
individuals in Nigeria and shall be linked thereto by their respective State Central bodies to be known as "State Councils for Islamic Affairs" which are referred to as "State Council". ${ }^{92}$ That means the NSCIA has over 70 Million followers since Nigeria has up to $50 \%$ Muslim population. ${ }^{93}$ There is no doubt the use of these important body can be used to educate and inform its followers on the evil of child trafficking.

The Constitution of the SCIA provided for the establishment of Committees as follows: ${ }^{94}$

(1) Elders' Committee;

(2) Fatwah Committee;

(3) Financial Committee;

(4) Da'awah Committee;

(5) Research and Policy Committee;

(6) Youth and Social Welfare Committee;

(7) Media Committee;

(8) International Relations Committee;

(9) Economic Affairs Committee; and

(10) Legal Affairs Committee; and

(11) Pilgrims Committee.

The National Executive Council may establish other Standing Committees as well as Ad-hoc Committee as may be found necessary. These committees will greatly help in the fight against Human Trafficking especially the Committees on Da'awah. Since there is room for the establishment of other standings committees, a standing committee could be established on the fight against human trafficking.

\section{b. The Christian Association of Nigeria}

The Christian Association of Nigeria is equally a very strong association that can play a very significant role in the fight against human trafficking. The Association is an umbrella body for all Christian Churches with distinct identities, recognizable Church structures and a system of worship. Before the coming the Association, Protestants and Catholics were not in good terms and there was competition over territories. In the words of Sundkler and Steed:

For centuries the two competing confessions, Catholic and Protestants, treated one another with damning silence-plodding along on different sides of the same hill or river, relying on the same vernacular related to the same traditional African religion, dealing with similar daily experiences in the district in hot season and rainy season-yet never meeting. The other party did not or should not exist. ${ }^{95}$

Among other factors the Decree on Ecumenism which opened the gate for unity between the Catholics and other Christian denominations greatly helped in bringing unity and indeed formation of the CAN (Christian Association of Nigeria). The Decree on Ecumenism reads:

The concern for restoring unity involves the whole Church, faithful and clergy alike. It extends to everyone, according to the talents of each, whether it be exercised in daily Christian living or in theological and historical studies. The concern itself already reveals to some extent the bond of brotherhood existing among all Christians, and it leads toward full and perfect unity, in accordance with what God in his kindness wills [...] there can be no ecumenism worthy of the name without interior conversion. For it is from newness of attitudes of mind (cf.Eph. 4:23), from self denial and unstinted love, that desires of unity take their rise and develop in a mature way. We should therefore pray

\footnotetext{
Article 4 Constitution of the Nigerian Supreme Council for Islamic Affairs.

Available at World Health Organization, "Global Status Report on Alcohol”, http://www.who.int/substance_abuse/publications/en/nigeria. $p d f$., accessed on 9 September, 2014.

94 Article 10 (3) Constution of the Nigerian Supreme Council for Islamic Affairs.

95 B. Sundkler and C. Steed, 2000, A History of the Church in Africa, Cambridge University Press, Cambridge, p. 5.
} 
to the Holy Spirit for the grace to be genuinely self-denying, humble, gentle in the service of others and to have an attitude of brotherly generosity toward them. ${ }^{96}$

Undoubtedly, the formulation of this decree is a watershed in Christian history. From this point the hearts of Catholics began to warm up towards their brethren from other denominational folds. In this way Vatican II prepared the ground for the emergence of CAN, and it gave the Catholic clergy in Nigeria the impetus and permission to lead their people towards co-operation with nonCatholic Christians. ${ }^{97}$

Having appreciated the effect lack of unity could have on the interest of Christians and Christianity in the post independence Nigeria, following several meetings and deliberations CAN was born on the 27th day of August 1976 as a Christian pressure group or, euphemistically put, a Christian 'interest-protection' association. The member churches of CAN during those early days were mainly the Catholic Church and the member churches of the Christian Council of Nigeria. ${ }^{98}$

The Christian Association of Nigeria is indeed a formidable Association that will greatly help in the fight against human trafficking in Nigeria. The fact that it has millions of followers apart, it is very organized and enjoys support from its followers. These facts have made the government very respectful of the views and positions taken by the Association. All these potentials of the Association can be utilized in the fight against human trafficking.

\section{Means of Fighting Child Trafficking}

The SCIA and CAN could adopt several strategies in their fight against child trafficking in Nigeria. These strategies include but not restricted to.

\section{a. Admonishment}

Admonishment is a very effective means of stopping wrong and encouraging good. Under Islamic law, admonishment is considered a very important aspect of the religion that is encouraged by the Glorious Qur'an and other authentic traditions of the Prophet (PBUH). The Qur'an provides:

You are the best nation produced [as an example] for mankind. You enjoin what is right and forbid what is wrong and believe in Allah. If only the People of the Scripture had believed, it would have been better for them. Among them are believers, but most of them are defiantly disobedient. ${ }^{99}$

The prophet (PBUH) equally said that "Whoever amongst you that sees a wrong being committed should prevent it with his hand, if he cannot then he should prevent it by his mouth, if he cannot then he should dislike it in his heart, that is the least of iman". ${ }^{100}$

These religious bodies should therefore admonish their followers on the evil of human trafficking. They should insist that even if a person escapes punishment in this world, the wrath of the Lord will certainly befall the person for his act of causing physical and psychological harm on an innocent child.

\section{b. Sanction}

Undoubtedly, these associations are not courts of law neither are they law enforcement agents hence lacking the power

\footnotetext{
96 Bauna Peter Tanko, 1991, The Christian Association of Nigeria and the Challenge of the Ecumenical Imperative, N. Domenici-Pecheux, Rome, pp. 11,12, 60

97 J.S. Rengshwat, "Christian Association of Nigeria: Politics and Ecumenism", www.tcnn.org/articles/RB50_Rengshwat.pdf, accessed on 1 September, 2014.

98 Ibid.

9 Qur'an 2:110

100 Hadist Bukhari and Muslim.
} 
to impose fine or sentence wrong doers to prison terms. However, they can in their own ways take practical steps towards ensuring that sanctions are placed on members that breach the law. Sanction does not necessarily have to monetary or physical, it could as well be psychological. These influential religious bodies can sanction their erring members through publicly disassociating themselves from such a member and his activities. They could refuse to accept gifts or donations from him and can as well decide to tell other members to isolate him. These steps can have far reaching psychological effects on persons that are involved in child trafficking and can therefore be a very effective means of stopping the activity.

Man as social animal cannot live in isolation and since the essence of such illegal business it to make money and live comfortably in the society as a respected person, the essence will definitely be defeated and will be a very important mechanism for stopping such an illegal activity. The effect of such sanction will not stop on just the individual involved especial when he is a bread winner of his family but will equally affect his immediate family such as his wife and children, since the head of their family is seen as rejected by the society or his religious bodies. The effect on the family will help in adding pressure on the person involved to stop his illegal activities because some people could withstand torture on their person but cannot withstand such harm to be done on their immediate family. The family will equally help in putting pressure on the person because of the negative effect of his activities on them.

Similarly, by boycotting such an individual, that means if the person has other business doing, such other business will be affected and thereby leading to financial sanction on the individual. The beauty of such drastic step is that it leads to financial loss on the individual thereby causing much harm to the wrong doer.

\section{c. Information Sharing}

Since these bodies are not law enforcement agents, they do not have the powers to arrest and sanction but they could be of great help by ensuring that they inform the appropriate authorities such as NAPTIP and the Police on the activities of a person that is believed to be involved in the act of child trafficking. If these information is made available to the appropriate authorities, they will take practical steps of ensuring that such a person is arrested and investigated. With such positive efforts, traffickers can easily be traced and prosecuted.

\section{d. Monitoring}

These religious bodies are close to the people they will be in a position to monitor the activities of the members of the community. The fight against crime in general or trafficking in particular cannot be left to the government alone. The society must join hands with the government in the fight against trafficking. The religious bodies must monitor the activities of its members and a special attention be given to people with suspicious character so that if they happen to be involved in child trafficking it will be known and appropriate action will be taken on persons found wanting.

\section{Conclusion}

Human trafficking is a global menace that is described as modern day slavery. There are several international human right instruments that have categorically condemned human trafficking. The victims of trafficking in persons are often women and children. While women and young girls are often trafficked for prostitution, domestic work and begging and boys are trafficked for labour such as working in restaurants and farms. Like most countries of the world, Nigeria has followed suit in 
the fight against trafficking in persons by passing into law a special law dedicated to the fight against trafficking in persons and establishment of NAPTIP which has recorded huge success in the fight against human trafficking in recent years.

A child according to the Convention on the Right of the Child and the Child's Right Act is any person below the age of 18 years. As a vulnerable human being, children easily fall victims of human trafficking through deception or by duress. Children trafficked from Nigeria are often taken to European countries and some Arab countries like Saudi Arabia. The traffickers of these children often take this illegal activity as a form of business and it involves a lot of agents.

The NSCIA and the CAN are two formidable religious organizations that enjoy followership from up to $90 \%$ of Nigerians. They are highly respected by their followers and by the government. The use of these organizations in the fight against child trafficking will definitely yield great results. These bodies can use admonishment, sanctions, monitoring and the sharing of information with the appropriate authorities as means of achieving positive results.

\section{REFERENCES}

\section{A. Books}

Busch-Armendariz, N.B., et al, 2009, Understanding

Human Trafficking: Development of Typologies of Traffickers, Institute on Domestic Violence and Sexual Assault, USA. Gallagher, A., et al, 2010, Recommended Principles and Guidelines on Human Rights and Human Trafficking, United Nations, New York.

ILO/IPEC, 2000, Combating Trafficking in Children for Labour in West and Central Africa, ILO/ IPEC, Geneva.

Koettl, J., 1999, Human Trafficking, Modern Day Slavery and Economic Exploitation, The World Band, Switzerland.

Sundkler, B. and C. Steed, 2000, A History of the Church in Africa, Cambridge University Press, Cambridge.

Tanko, Bauna Peter, 1991, The Christian Association of Nigeria and the Challenge of the Ecumenical Imperative, N. DomeniciPecheux, Rome.

\section{B. Journal Articles}

Adepoju, A., "Review of Research and Data on Human Trafficking in Sub Saharan Africa", International Migration, Vol. 43, No. 1/3, 2005.

Agbu, O., "Corruption and Human Trafficking: the
Nigerian Case", West African Review, Vol. 4, No. 1, 2003.

David, A.M., Odigie, "Human Trafficking Trends in Nigeria and Strategies for Combating the Crime", Peace Studies Journal, Vol.1, No. 1, 2008.

E.J.C., Duru and Maurice O.U., "Combating Human Trafficking in Nigeria: An Evaluation of State Policies and Programmes", Mediterranean Journal of Social Sciences, Vol. 3, No. 3, September 2012.

Enaikele, M.D., and A.O. Olutayo., "Human trafficking in Nigeria: Implication for Human Immune Deficiency Virus and Acquired Immune Deficiency Syndrome (HIV/ AIDS) Pandemic", International Journal of Sociology and Anthropology, Vol. 3, No. 11, 2011.

Erudice, M.S., "Fighting Human Trafficking in Countries of Origin and Destination Improving Multidisciplinary Cooperation Between Nigeria and European Countries", SAIK Journal, Vol. 1, 2012.

Geshinde, A.M., and A. Elegbeleye, "An Investigation into Push Factors Sustaining Human Trafficking in Nigeria", Journal of Functional Management, Vol. 4, No. 1, 2001. Jorge-Birol1, A.P., "Empowering Victims of Human 
Trafficking: the Role of Support, Assistance and Protection Policies", HUMSEC Journal, Issue 2.

Moossy, R., "Sex Trafficking: Identifying Cases and Victims", NIJ Journal, Issue No. 262, 2010.

Rahman, M.A., "Human Trafficking in the era of Globalization: the Case of Trafficking in the Global Market Economy", Transcience Journal, Vol. 2, No. 1, 2011.

Rufai, S.A., "The Politics of Islamic Leadership and Representation in Nigeria: A Historical Analytical Study on the Nigerian Supreme Council for Islamic Affairs (NSCIA)", Jurnal Al-Tamaddun Bil, Vol. 8, No. 1, 2013.

Zimmerman, Y.C., "Christianity and Human Trafficking”, Religion Compass, Vol. 5, No. 10, 2011.

\section{Edited Books, Anthologies}

Melrose, M., "Young People and Sexual Exploitation: A Critical Discourse Analysis", in M. Melrose, 2013, Critical Perspectives on Child Sexual Exploitation and Related Trafficking, Palgrave Macmillan, Hampshire.

\section{Newspapers and Magazines}

Agbu, O., Daily Times of 14 June 2001.

\section{Websites}

Council of Europe, "Action Against Trafficking in Human Beings", http://www.coe.int/ trafficking, accessed on 12 August, 2014.

Department of State United States of America, "Trafficking in Persons Report", http://www. state.gov/documents/organization/142979. $p d f$, accessed on 6 September 2014.

Feingold, D.A., "Think Again Human Trafficking", http://faculty.maxwell.syr. edu/hpschmitz/PSC350/PSC350Readings/ ThinkAgainHumanTrafficking.doc, accessed on 12 August 2014.

King L., "International Law and Human Trafficking", https://www.du.edu/korbel/hrhw/ researchdigest/trafficking/InternationalLaw. pdf, accessed on 9 September 2014.

Ogbu, O., "Revisiting Corruption and Human Trafficking in Nigeria: Any Progress?", http://www.ungift.org/docs/ungift/pdf/ $v f /$ backgroundpapers/OsitaAgbu_1.pdf, accessed on 30 August 2014.

Opara, V.N., "Consent Dilemmas: Contextualising the Trafficking of African, Asian, \& Eastern European Women for Prostitution", http:// aa.ecn.cz/img_upload/9e9f2072be82f3d6 9e3265f4lfe9f28e/VOpara_Dilemma_of Consent_after_Alices_review.pdf., accessed on 8 September 2014.

Rengshwat, J.S., "Christian Association of Nigeria: Politics and Ecumenism", www.tcnn.org/ articles/RB50_Rengshwat.pdf, accessed on 1 September, 2014.

The Muslim 500, “Amirul Mu'minin Sultan Muhammadu Sa'adu Abubakar III", http:// themuslim500.com/profile/saadu-abubakariii-sultan-sokoto, accessed on 19 August 2014.

United Nations Human Rights, "Office of the Commissioner for Human Rights", http:// www.ohchr.org/en/udhr/pages/introduction. aspx, accessed on 9 September 2014.

United Nations International Children's Fund, "Child Protection", http://www.unicef.org/ dump/9482.html, accessed on 6 September 2014.

United Nations Human Rights, "Reporting Status for Nigeria", http://tbinternet.ohchr.org/_ layouts/TreatyBodyExternal/Countries. aspx? CountryCode $=N G A \& L$ ang $=E N$, accessed on 23 January 2014.

United Nation Office on Drugs and Crime, "Conference of the Parties to the United Nations Convention Against Transnational Organized Crime and the Protocols Thereto", http://www.unodc.org/unodc/treaties/ CTOC/, accessed on 2 September 2014.

World Health Organization, "Understanding and Addressing Violence Against Women", http:// www.who.int/iris/bitstream /10665/77394/1/ 
WHO_RHR_12.42_eng.pdf, accessed on 27 August 2014.

World Health Organization, "Global Status Report on Alcohol", http://www.who.int/substance abuse/publications/en/nigeria.pdf., accessed on 9 September 2014.

\section{Regulations}

Constitution of the Federal Republic of Nigeria 1999.

Matrimonial Causes Act (CAP M7 Laws of the Federation of Nigeria 1970).

Child's Right Act (CAP M7 Laws of the Federation of Nigeria 2004).

Children and Young Persons Act (CAP 22 Laws of the Federation of Nigeria 2004).

Immigration Act (CAP 171 Laws of the Federation of Nigeria 1963).
Marriage Act (CAP C218 Laws of the Federation of Nigeria 1990).

Criminal Code (CAP C38 Laws of the Federation of Nigeria 2004).

Penal Code (CAP P3 Laws of the Federation of Nigeria 2004).

Labour Act (CAP L1 Laws of the Federation of Nigeria 2004).

Trafficking in Persons Law Enforcement and Administration Act (CAP 24 Laws of the Federation of Nigeria 2003).

Protocol to prevent, suppress and punish trafficking in persons, especially women and children, supplementing the United Nations convention against transnational organized crime, G.A. res. 55/25, annex II, 55 U.N. GAOR Supp. (No. 49) at 60, U.N. Doc. A/45/49 (Vol. I) (2001), entered into force on 25 December 2003. 